\title{
Anti-Nutritional Factors of Green Leaves of Cassia obtusifolia and Kawal
}

\author{
Algadi $\mathrm{MZ}^{1 *}$ and Yousif $\mathrm{NE}^{2}$
}

${ }^{1}$ Arab Center for Nutrition, Muharraq, Bahrain

${ }^{2}$ Food Science and Technology, Khartoum University, Sudan

\begin{abstract}
Cassia obtusifolia (family leguminous) is a wild African plant found in wastelands in the rainy season. Its leaves can be fermented (named kawal) and is used by people from the eastern part of Chad and the western part of Sudan as meat replacer or meat extender. The role of kawal and the like is in providing the sauces which make these staples palatable. During famine years, kawal, a protein source, probably protected many children against kwashiorkor. Until a few years ago, kawal was little known to most Sudanese, for it was a product confined to the western provinces of the country, away from populated areas and centers of influence. Then as today, kawal was shunned by the elite who consider it unfit for modern social life because of its repugnant, fetid odor that lingers on the fingers for hours. The objectives of this study were to assess the effect of fermentation on anti-nutritional factors of Cassia obtusifolia leaves. The in vitro protein digestibility was significant $(\mathrm{P}<0.05)$ increased from 49.43 to $61.87 \%$. It is recommended to use fermentation to decrease anti-nutritional factors of Cassia obtusifolia.
\end{abstract}

Keywords: Fermentation; Kawal; Anti-nutrutional; Phytic; Tannin

\section{Introduction}

The fermentation process that an African woman employed was behind the dramatic improvement in the protein value of the food [1]. The fermentation of meals of cereal and legumes knows to increases the protein content [2]. The international community of food scientists has, in the past decades, shown a deep interest in three areas of food science and technology. The first of these is the area of indigenous fermented foods, where a preponderance of literature has revealed interesting facts including a substantial enhancement of the food as a result microbial growth in it [3]. The second field of interest is the areas of solid substrate fermentation in which the substance to be fermented albeit wet, is not fluid [4]. The third area is that of leaf protein [5]. Scientists, in their relentless quest for new protein sources to help feed an ever-increasing world population, found that the plant leaf can be a truly commendable candidate. Cassia obtusifolia (family leguminous) is a wild African plant found in wastelands in the rainy season. Its leaves can be fermented (named kawal) and is used by people from the eastern part of Chad and the western part of Sudan as meat replacer or meat extender [6]. The role of kawal and the like is in providing the sauces which make these staples palatable. During famine years, kawal, a protein source, probably protected many children against kwashiorkor. Until a few years ago, kawal was little known to most Sudanese, for it was a product confined to the western provinces of the country, away from populated areas and centers of influence. Then as today, kawal was shunned by the elite who consider it unfit for modern social life because of its repugnant, fetid odor that lingers on the fingers for hours. The objectives of this study was to assess the effect of fermentation on the anti-nutritional factors of Cassia obtusifolia.

\section{Material and Methods}

\section{Kawal preparation method}

In kawal fermentation according to [6], the green leaves are first freed of all extraneous matter, such as leaves of other plants, pods and flowers of the kawal plant itself, caterpillars and insect-damaged leaves. This process of sorting out the kawal leaves is strictly observed and in fact this part of the preparation procedure is the most tedious step as it takes hours of painstaking work. Green flower buds and delicate young pods may, however, be processed with the green leaves. The unwashed, healthy green leaves, now clean from all adulteration are beaten in a mortar-and -pestle to give a green paste. Pounding is done in such a way that the leaves are crushed without releasing their juice. In the final paste can be seen partially crushed leaves, twigs, mid-ribs and petioles. Meanwhile, a pit is dug in the ground in a shaded cool place. And earthenware pot (Burma) is fitted into the pit, leaving only the neck of the container above ground. The green paste is now packed into the pot by hand. Next, green sorghum leaves are folded onto the surface of the leaf paste in the Burma so that it is completely covered. Washed, dry stones are then placed on top of the sorghum leaves to weight them down. The mouth of the pot is then covered with some metal tray or dish and the whole sealed off with mud to prevent insect from entering. Every 3-4 days the jar is opened, the now yellow and dry sorghum leaves removed and the Burma thoroughly hand-mixed and repacked, this time a little loose. Fresh sorghum leaves are folded on the surface of the past and weighted down as before the Burma covered and sealed off again. The paste is next molded into small. Irregular balls or flattish cakes which are then sun dried for 3-4 days. The duration of the fermentation is about 25 days for the supply of an average family. Cassia obtusifolia leaves and kawal were obtained in dry form after been sun dried and freed from foreign materials and powdered by hummer mill with same mesh size and was kept in clean bottles at room temperature for further use.

\section{Anti-nutritional factors determination}

Determination of phytic acid content: Phytic acid content was determined by the method described by Wheeler and Ferrel [7]. Two grams of dried sample were weighted in $125 \mathrm{ml}$ conical flask. The sample was extracted with $50 \mathrm{ml}$ of $3 \%$ trichloroacetic acid (TCA) for $3 \mathrm{hr}$ with mechanical shaking. The supernatant was centrifuged for $5 \mathrm{~min}$. ten milliliters aliquot of the supernatant was transferred to a $40 \mathrm{ml}$ tube

*Corresonding author: Algadi MZ, Arab Center for Nutrition, Muharraq, Kingdom of Bahrain, Tel: +973-33111595; E-mail: mutasim.algadi@gmail.com

Received April 10, 2015; Accepted July 03, 2015; Published July 10, 2015

Citation: Algadi MZ, Yousif NE (2015) Anti-Nutritional Factors of Green Leaves of Cassia obtusifolia and Kawal. J Food Process Technol 6: 483. doi:10.4172/21577110.1000483

Copyright: @ 2015 Algadi MZ, et al. This is an open-access article distributed under the terms of the Creative Commons Attribution License, which permits unrestricted use, distribution, and reproduction in any medium, provided the original author and source are credited. 
and $4 \mathrm{ml}$ of $\mathrm{FeCl}_{3}$ ( $\mathrm{Fecl}_{3}$ solution containing $2 \mathrm{mg} \mathrm{Fe}{ }^{+3}$ ion $/ \mathrm{ml} 3 \% \mathrm{TCA}$ ) were then added to the aliquot. The tube was heated in a boiling water bath for $45 \mathrm{~min}$. One or two drops of $3 \%$ sodium sulphate $\left(\mathrm{Na}_{2} \mathrm{SO}_{4}\right)$ in $3 \%$ TCA were added the tube was cooled and centrifuged for 10-15 min and the clear supernatant was decanted. The precipitate was washed by dispersing well in $25 \mathrm{ml} \mathrm{3 \%}$ TCA, heated for 10-15 min in boiling water bath and then centrifuged again. Washing was repeated with distilled water, the washed precipitate was dispersed in few milliliters of distill water enriched with $3 \mathrm{ml}$ of $1.5 \mathrm{~N} \mathrm{NaOH}$, and the volume completed to approximately $30 \mathrm{ml}$ with distilled water. Heated on boiling water bath for $30 \mathrm{~min}$ and hot filtered using whatman No.2. The precipitate was washed with $60-70 \mathrm{ml}$ hot water, and the washing was decanted. The precipitate from the filter paper was dissolved in $40 \mathrm{ml}$ hot $3.2 \mathrm{~N} \mathrm{HNO}_{3}$ and placed in $100 \mathrm{ml}$ volumetric flask. The paper was washed with hot distilled water and the washing was collected in the same flask then completed to volume. A $0.5 \mathrm{ml}$ of aliquot was taken from the above solution and transferred into $10 \mathrm{ml}$ volumetric flask. then $2 \mathrm{ml}$ of $1.5 \mathrm{~N}$ $\mathrm{KSCN}$ (potassium ) were added and completed to volume by water then immediately (with one min) read at $480 \mathrm{~nm}$ using (SP6 PyUnieam) spectrophotometer.

A standard curve of different $\mathrm{Fe}\left(\mathrm{NO}_{3}\right)^{3}$ concentrations was plotted to calculate the ferric ion concentration. The phytate phosphorus was calculated from the Iron concentration assuming 4:6 Iron to phosphorus molar ration.

$$
\text { Phytate }(\mathrm{mg} / 100 \mathrm{~g})=\frac{6 / 4 \mathrm{~A} \times \mathrm{C} \times 20 \times 10 \times 50 \times 100}{1000 \times \mathrm{S}}
$$

Where:

$$
\begin{aligned}
& \text { A = optical density } \\
& C=\text { concentration corresponding to optical density } \\
& \text { S = weight of sample }
\end{aligned}
$$

Determination of tannin content: Tannin content (TC) of Cassia obtusifolia leaves and kawal samples were estimated using modified vanillin- $\mathrm{HCl}$ in methanol as described by Price et al. [8]. About $0.2 \mathrm{~g}$ of ground sample was placed in $100 \mathrm{ml}$ conical flask. $10 \mathrm{ml}$ of $1 \% \mathrm{Hcl}$ in methanol (v/v) were added, the contents were mechanical shaking for $20 \mathrm{~min}$ and centrifuged at $2500 \mathrm{rpm}$ for $5 \mathrm{~min}$. One $\mathrm{ml}$ of supernatant was pipettes into a test tube and $5 \mathrm{ml}$ of vanillin-Hcl reagent (mixing equal volume of $8 \%$ concentrated $\mathrm{Hcl}$ in methanol and $1 \%$ vanillin in methanol) were added. The optical density was read using a colorimeter (Lab system Analyzer 9 filters, j, Mitra and Bros.Pvt .Ltd.) at $500 \mathrm{~nm}$ after $20 \mathrm{~min}$ incubation at $30^{\circ} \mathrm{C}$, a blank sample was carried out with each run of samples. A standard curved was repeated expressing the result of tannic acid, i.e. amount of tannic (mg per $\mathrm{ml}$ ) which gives color intensity equivalent to that given by tannin after correcting for blank.

\section{Calculation:}

$$
\mathrm{TC}(\%)=\underline{\mathrm{C} \times 10 \times 100}
$$

Where:

$$
\begin{aligned}
& \mathrm{C}=\text { concentration corresponding to optical density } \\
& 10=\text { volume of extract in } \mathrm{ml} \\
& 200=\text { sample weight in } \mathrm{mg}
\end{aligned}
$$

Total polyphenol (TP) determination: Polyphenolic of each sample was estimated using Prussian blue assay, as described by Price and Butter [9]. About $60 \mathrm{mg}$ of ground sample was extracted with $3 \mathrm{ml}$ methanol in a $50 \mathrm{ml}$ conical flask, and then poured into a filter paper. The tube was quickly rinsed with additional $3 \mathrm{ml}$ methanol and the content poured once into the filter paper. the filtrate was diluted to $50 \mathrm{ml}$ with distilled water, mixed with $3 \mathrm{ml} 0.1 \mathrm{M} \mathrm{Fecl}_{3}$ in $0.1 \mathrm{~N} \mathrm{Hcl}$ for $3 \mathrm{~min}$, followed by the time addition of $3 \mathrm{ml} 0.008 \mathrm{M} \mathrm{K}_{3} \mathrm{Fe}(\mathrm{CN})_{6}$. The absorption was read after $10 \mathrm{~min}$ at $720 \mathrm{~nm}$ on spectrophotometer (corning, 259).

Standard curve preparation: Tannic acid standard curve was prepared by dissolving $100 \mathrm{mg}$ tannic acid in distilled water in a 0.1 liter volumetric flask and made up to mark. This spread stock solution of $100 \mathrm{ppm}$. Various standard concentrations (0, 2, 4, 6, 8 and 10) were repeated. The Prussian blue assay described above was then employed to the standard solution. The standard curve was obtained by plotting concentration against the corresponding absorbance reading, which gave linear relationship.

Calculation:

Total polyphenol $(\%)=\underline{\mathrm{C} \times 56 \times 100}$

60

Where,

$$
\begin{aligned}
& \text { C }=\text { concentration corresponding to optical density } \\
& 56=\text { total volume } \\
& 60=\text { weight of sample in milligrams }
\end{aligned}
$$

\section{Results and Discussion}

Anti-nutritional factors of green leaves of Cassia obtusifolia and kawal is shown on Table 1. Fermentation was found to cause highly significant decrease $(\mathrm{p}>0.05)$ in phytic acid content. The phytic acid content was decreased from 649.13 to $340.92 \mathrm{mg} / 100 \mathrm{~g}$. Generally fermentation is known to cause highly reduction in phytic acid content due to the low $\mathrm{pH}$ of fermented dough which considered to be optimum for the phytase activity. Fermentation was found to cause highly significant decrease $(\mathrm{p}>0.05)$ in tannin content. The tannin content was decreased from 2.39 to $2.24 \%$. The values obtained in this study were in agreement with the value obtained by Babiker et al. [10] who reported that the tannin content of green leaves of Cassia obtusifolia 2.34\%. But lower than the value obtained by Abdalla [11] who reported 2.50\% for tannin content of green leaves of Cassia Obtusifolia. Fermentation was found to cause degradation of tannin content and this may be due to the action of enzymes. Fermentation was found to cause highly significant decrease $(\mathrm{p}>0.05)$ in total polyphenol content. The total polyphenol content was decreased from 4.77 to $3.80 \%$. The total polyphenol of green leaves of Cassia obtusifolia in this study were in agreement with the value obtained by Ousman et al. [12] who was

\begin{tabular}{|l|l|l|l|}
\hline sample & Tannin \% & Phytic acid mg/100g & Polyphenol \% \\
\hline $\begin{array}{l}\text { Cassia obtusifolia } \\
\text { Leaves }\end{array}$ & $2.39( \pm 0.012)^{\mathrm{a}}$ & $649.13( \pm 7.137)^{\mathrm{a}}$ & $4.77 \mathrm{~m}( \pm 0.252)^{\mathrm{a}}$ \\
\hline Dry Kawal & $2.24( \pm 0.021)^{\mathrm{b}}$ & $340.92( \pm 5.952)^{\mathrm{b}}$ & $3.80( \pm 0.200)^{\mathrm{b}}$ \\
\hline
\end{tabular}

- Each value in an average of three values expressed on dry weight basis. Values are means ( \pm standard deviation).

Means not sharing a common letter in a column are significant at $p \geq 0.05$ as assessed by Duncan's multiple range tests.

Table 1: Anti-nutritional factorof green leaves of Cassia obtusifolia and kawal (as dry matter). 
Citation: Algadi MZ, Yousif NE (2015) Anti-Nutritional Factors of Green Leaves of Cassia obtusifolia and Kawal. J Food Process Technol 6: 483. doi:10.4172/2157-7110.1000483

Page 3 of 3

reported $4.8 \%$. Reduction in polyphenols may be due to activation of polyphenol oxidase [13].

\section{References}

1. Dirar HA (1992) Traditional fermentation technologies and food policy in Africa. Appropriate technology 19: 21-23.

2. Tinay AHE, Gadir AHA, Hidai ME (1979) Sorghum fermented Kisra bread. 1: nutritive value of Kisra. Journal of Science Food and Agriculture 30: 859-563.

3. Steinkrause $\mathrm{KH}$ (1978) Contribution of Asian fermented foods to international food science and technology. Global Impacts in Applied Microbiology 5: 173-179.

4. Stanton WR (1978) Solid-substrate fermentation. Global impacts in applied microbiology 5: 180-189.

5. Pirie NW (1978) Leaf protein and other aspects of fodder fraction. Cambridge press, UK.

6. Dirar HA (1993) The Indigenous Fermented food of the Sudan. A study of African Food and Nutrition. CAB International, Walling ford.
7. Wheeler EL, Ferrel RE (1971) A Method for phytic acid determination in wheat and wheat fractions. American Association of Cereal chemists 28: 313-320.

8. Price ML, Scoyoc SV, Butler LG (1978) A critical evaluation of the vanillin reaction as an assay for tannin in sorghum grain. Agricultural Food Chemistry 26: $1214-1218$.

9. Price ML, Butler LG (1977) Rapid visual estimation and spectrophotometric determination of tannin content of sorghum grain. Journal of Agriculture and Food Chemistry 25: 1268-1273.

10. Babiker A, Khalifa AEO, El Tinay AH (1998) A note on the effect of tannin content and the in vitro protein digestibility of some Sudanese flora. Journal of agricultural sciences 6: 157-161.

11. Abdalla ZED (1989) Studies on the chemical composition, Phenolic and polyphenolic constituents of some leafy vegetables consumed in Sudan. University of Khartoum, Sudan.

12. Ousman A, Ngassoum M, Kamga C (2005) Chemical composition of Cassia Obtusifolia L. leaves. Journal of Food Technology 3: 453-455.

13. Dhanker N, Chauhan BM (1987) Effect of temperature and fermentation time on phytic acid and polyphenol content of rabadi - A fermented pearl millet food. Journal of Food Science 52: 828-829. 